\title{
Impact of type of wastewater treatment process on the antibiotic resistance of bacterial populations
}

\author{
Adriana Osińska ${ }^{1,{ }^{*}}$, Ewa Korzeniewska ${ }^{1}$, Monika Harnisz ${ }^{1}$, and Sebastian Niestępski ${ }^{1}$ \\ ${ }^{1}$ Department of Environmental Microbiology, Faculty of Environmental Sciences, University of \\ Warmia and Mazury in Olsztyn, Poland
}

\begin{abstract}
Antibiotic resistant bacteria reach the environment directly with faeces, and indirectly with sewage discharged from wastewater treatment plants (WWTPs). The aim of the study was to determine the level of removal of bacteria during wastewater treatment. Samples of untreated and treated sewage were collected from 13 WWTPs with different capacity, modification of treatment and type of inflowing wastewater. Microbiological characterization of the samples included determination of the total number of bacteria resistant (ARB) to $\beta$-lactams and tetracyclines as well as the number of Escherichia coli resistant to the same drugs. The counts of ARB and E. coli were determined on TSA and $\mathrm{mFc}$ media with/without antibiotic supplementation, respectively. The highest percent of reduction in number of ARB (at least 99.9\%) and E. coli (above 99.3\%) was obtained for WWTPs with $\mathrm{A}_{2} \mathrm{O}$ system. The lowest percentage reduction of ARB and E. coli was observed for WWTPs operating with SBR system. The lowest number of microorganisms resistant to analyzed antibiotics was observed for ARB and E. coli resistant to cefotaxime and doxycycline. The results indicate a large variation in the removal of antibiotic-resistant bacteria in WWTPs depending on modifications of treatment system and type of inflowing wastewater.
\end{abstract}

\section{Introduction}

The overuse of antibiotics in medicine and agriculture caused a reduction of their efficacy against most of infectious diseases. According to the World Health Organization (WHO), the increase of antibiotic resistance among bacteria is one of the most important global problems [1]. In addition, according to the report prepared by O'Neill [2] due to infections caused by bacteria resistant to antimicrobial agents, 700,000 people die every year, and by 2050 this number is expected to grow to over 10 million. The definition of drug-resistant bacteria given by ECDC [3] is based on the limit values relating to the clinical strains. That is why it seems necessary to have an alternative approach to the microbial characteristics of environmental strains [4]. However, so far there is no

*Corresponding author: adriana.osinska@uwm.edu.pl 
exhaustive data allowing to assess the consequences of the occurence of antibiotic resistance in environmental bacteria.

Another global problem is the access to safe and clean water [5]. It should be remembered that water resources are decreasing dramatically all over the world, especially due to global warming and climate change [6]. The discharge of treated sewage with a high burden of drug-resistant microbes into the surface water reservoirs may prevent their further use for economical purposes. The adverse effect of the phenomenon of antibiotic resistance on the health of both humans and animals, as well as its economic impact, enforces taking actions which objective is to monitor the spread of the antibiotic resistance in microorganisms of aqueous environments [7].

The occurrence and growth of antibiotic resistance in microorganisms populations are inevitable and conditioned by changes in the way of evolution, because bacteria can be quickly adapted to changing environmental conditions [8]. Antibiotic resistance may be intrinsic in the bacteria with a natural predisposition for recombination and genetic mutation or acquired as a result of selective pressure of antimicrobial substances present in the environment [9]. It may also be the result of a process of horizontal gene transfer between microorganisms using of mobile genetic elements (plasmids, transposons, integrons) $[10,11]$.

Wastewater treatment plants are considered as an important reservoir (hot-spots) of antibiotic-resistant bacteria (ARB), and antibiotic resistance genes (ARGs) [12-14] representing a major source of their dissemination in the environment $[15,16]$. The wastewater flowing into WWTPs create favorable conditions for the survival of ARB and transfer of ARGs, due to the high content of both microbial biomass and the nutrients [13].

Safe and simultaneously economically reasonable methods of discharges of the treated wastewater to the environment are a major challenge in the management of wastewater. Nowadays, technology of treatments is primarily focused on the removal of contaminations such as organic matter, nitrogen and phosphorus compounds, which can cause oxygen depletion and eutrophication of waters receiving treated wastewater. However, they do not focus on the removal of ARB and ARGs [16]. Quantitative determination of the presence of indicators of fecal contamination such as Escherichia coli and Enterococcus faecalis, taken into consideration in the evaluation of surface water, is also recommended by many authors to assess the microbiological quality of wastewater $[17,18]$.

Although there has been a reduction in the number of bacteria at the level $99 \%$ in the process of treatment and disinfection of wastewater, together with the WWTPs' effluents the significant amounts of ARB enter into the environment. These ARB are characterized by higher resistance to antibiotics due to the transfer of genes between bacteria present in the wastewater [19]. Their higher number is still observed in the treated sewage [20, 21], which can be transferred to subsequent environments, posing a potential threat to their safety and public health. Therefore, in this article we compare the use of various modifications of the wastewater treatment technologies based on activated sludge in the removal of both the total number of antibiotic-resistant bacteria and E. coli resistant to the most commonly used class of antibiotics which are beta-lactams and tetracyclines.

\section{Materials and methods}

\subsection{Study sites and sampling}

Samples of untreated and treated sewage was collected from 13 WWTPs located in Warmia and Mazury District. WWTPs treat the wastewater based on activated sludge with different modification (biological, biological with elevated nutrient removal) and type of 
inflowing wastewater (domestic sewage, hospital sewage, wastewater from food industry), various capacity and number of population served. Wastewater treatment plant were divided into 4 categories, due to the applied modification of sewage treatment system: A - WWTPs with $\mathrm{A}_{2} \mathrm{O}$ system, B - WWTPs with mechanical-biological system, C - WWTPs with SBR reactors, D - WWTPs with mechanical-biological system with elevated removal of nutrients. Samples of wastewater were collected in summer (July) and in winter (February) into the sterile bottles, transported to the laboratory at the temperature of $4^{\circ} \mathrm{C}$ and processed on the day of collection.

\subsection{Physicochemical parameters}

The level of physicochemical parameters value of wastewater samples, including biochemical oxygen demand over 5 days (BOD) and chemical oxygen demand (COD) of sewage were evaluated in parallel to microbial analysis. The methodology to assess those parameters was used in accordance with the APHA [22]standard methods.

\subsection{Number of bacteria and bacteria resistant to antibiotics}

To obtain 8-80 colony forming units (CFU) per plate, untreated wastewater (UWW) and treated wastewater (TWW) samples were decimal diluted with saline water and passed through a cellulose filter (pore diameter $0.45 \mathrm{uM}$, Millipore). Greater accuracy was achieved by plating triplicates. The total number of bacteria and bacteria resistant to $\beta$-lactams (amoxicillin, cefotaxime) and tetracyclines (oxytetracycline, doxycycline) as well as the total number of Escherichia coli and Escherichia coli resistant to the same drugs was determined on plates containing the TSA medium (Oxoid) and the mFc Agar medium (Merck) with/without amoxicillin $(2 \mu \mathrm{g} / \mathrm{mL})$, cefotaxime $(2 \mu \mathrm{g} / \mathrm{mL})$, oxytetracycline (2 $\mu \mathrm{g} / \mathrm{mL})$ and doxycycline $(2 \mu \mathrm{g} / \mathrm{mL})$ supplementation. Antimicrobial dose was determined in accordance to EUCAST [23] guidelines. The total number of microorganisms were incubated at $30^{\circ} \mathrm{C}$ for $48 \mathrm{~h}$. E. coli were cultured at $44.5 \pm 0.2^{\circ} \mathrm{C}$ for $24 \mathrm{~h}$ and after incubation, E. coli colonies were counted based on the number of dark blue colonies formed on the mFc Agar medium.

\subsection{Data analyses}

Statistical analyses were carried out using the STATISTICA 10 software package (StatSoft Inc., 1984-2011). The data were not normally distributed, and the Kruskal-Wallis test, a non-parametric version of the classical one-way analysis of variance (ANOVA), was used to determine variations in the abundance of the studied bacterial groups and the physicochemical parameters of samples from different groups of WWTPs. The Spearman's rank correlation was used to detect the correlations between physicochemical parameters and microbial counts.

\section{Results and discussion}

\subsection{Physicochemical parameters concentration}

The highest average values of BOD in UWW were found in samples from WWTPs in group B $(606 \mathrm{mg} / \mathrm{L})$, while the lowest were found in samples from WWTPs belonging to group A $(401 \mathrm{mg} / \mathrm{L})$. During the process of wastewater treatment in all analyzed WWTPs, BOD values of were reduced in $97-99.8 \%$. In contrast, the highest values of COD were 
observed among UWW samples from WWTPs belonging to group D $(1540 \mathrm{mg} / \mathrm{L})$, whereas the lowest were found in UWW samples from WWTPs of group C $(1199 \mathrm{mg} / \mathrm{L})$. COD values in the treatment process were diminished at percentage reduction of $92-98 \%$. Both of those parameters were directly positively correlated with the number of microorganisms analyzed in this study $(\mathrm{p}<0.05)$.

\subsection{The total number of bacteria and antibiotic-resistant bacteria to beta- lactams and tetracyclines}

The average total number of bacteria in untreated wastewater ranged from $1.47 \times 10^{7}$ to $6.05 \times 10^{7} \mathrm{CFU} / \mathrm{mL}$, while in the treated wastewater from $8.25 \times 10^{4}$ to $2.77 \times 10^{5} \mathrm{CFU} / \mathrm{mL}$. After the treatment process, the total number of bacteria was decreased by the level of 91.12 to $99.99 \%$ (Table 1). The lowest percentage of reduction was observed in WWTPs from group $\mathrm{C}$, while the highest one was noticed in WWTPs from group A.

Table 1. Total counts of bacteria, counts of bacteria resistant to beta-lactams (amoxicillin, cefotaxime) and tetracycline (oxytetracycline, doxycycline).

\begin{tabular}{|c|c|c|c|c|c|c|c|c|}
\hline & \multicolumn{2}{|c|}{$\mathbf{A}^{*}$} & \multicolumn{2}{|c|}{$\mathbf{B}^{*}$} & \multicolumn{2}{|c|}{$\mathbf{C}^{*}$} & \multicolumn{2}{c|}{$\mathbf{D}^{*}$} \\
\cline { 2 - 9 } & $\mathbf{U W W}^{*}$ & TWW $^{* *}$ & $\mathbf{U W W}^{*}$ & TWW $^{* *}$ & $\mathbf{U W W}^{*}$ & $\mathbf{T W W}^{* *}$ & $\mathbf{U W W}^{*}$ & $\mathbf{T W W}^{* *}$ \\
\hline TB & $60.5 \pm 41$ & $\begin{array}{c}27 \pm 26 \\
(99.7-99.9)\end{array}$ & $27 \pm 10$ & $\begin{array}{c}8.3 \pm 3.7 \\
(68-99.6)\end{array}$ & $15 \pm 8$ & $\begin{array}{c}22 \pm 19 \\
(91-99.9)\end{array}$ & $15 \pm 8$ & $\begin{array}{c}9 \pm 2.8 \\
(98.8-99.5)\end{array}$ \\
\hline TBA & $16 \pm 8.5$ & $\begin{array}{c}2.6 \pm 2 \\
(99.96)\end{array}$ & $16 \pm 4$ & $\begin{array}{c}8 \pm 3 \\
(0-99.8)\end{array}$ & $8.4 \pm 1.7$ & $\begin{array}{c}11 \pm 8.9 \\
(95-99.9)\end{array}$ & $6 \pm 1$ & $\begin{array}{c}8 \pm 3 \\
(96.7-99.39)\end{array}$ \\
\hline TBC & $1.98 \pm 0.9$ & $\begin{array}{c}2.9 \pm 2 \\
(94-95.7)\end{array}$ & $1.4 \pm 0.6$ & $\begin{array}{c}1.3 \pm 0.7 \\
(25-99.8)\end{array}$ & $1.3 \pm 0.7$ & $\begin{array}{c}0.4 \pm 0.2 \\
(96.7-99.9)\end{array}$ & $0.6 \pm 0.01$ & $\begin{array}{c}0.7 \pm 0.4 \\
(98.7-99)\end{array}$ \\
\hline TBO & $2.8 \pm 1.9$ & $\begin{array}{c}1.1 \pm 1 \\
(99.6-99.9)\end{array}$ & $1.9 \pm 0.5$ & $\begin{array}{c}1.5 \pm 0.7 \\
(47.5-99.5)\end{array}$ & $0.9 \pm 0.3$ & $\begin{array}{c}3.6 \pm 3 \\
(82-99.9)\end{array}$ & $0.7 \pm 0.3$ & $\begin{array}{c}0.5 \pm 0.1 \\
(98-99.5)\end{array}$ \\
\hline TBD & $2.7 \pm 2$ & $\begin{array}{c}0.01 \pm 0.002 \\
(94-99.3)\end{array}$ & $0.03 \pm 0.01$ & $\begin{array}{c}0.1 \pm 0.005 \\
(94-99.9)\end{array}$ & $0.03 \pm 0.01$ & $\begin{array}{c}0.14 \pm 0.1 \\
(79-99.8)\end{array}$ & $0.06 \pm 0.01$ & $\begin{array}{c}0.07 \pm 0.003 \\
(98-99)\end{array}$ \\
\hline
\end{tabular}

${ }^{*} \mathrm{CFU} / \mathrm{mLx} 10^{6} \quad{ }^{* *} \mathrm{CFU} / \mathrm{mLx} 10^{4} \quad{ }^{* * *} \%$ percent of reduction in the brackets

$\mathrm{CFU}$ - colony forming unit, UWW - untreated wastewater, TWW - treated wastewater, TB - counts of total bacteria, TBA - counts of bacteria resistant to amoxicillin, TBC - counts of bacteria resistant to cefotaxime, TBO - counts of bacteria resistant to oxytetracycline, TBD - counts of bacteria resistant to doxycycline, A, B, C, D - modification of sewage treatment system.

The average number of bacteria resistant to beta-lactams and tetracycline in the untreated wastewater ranged from $7.04 \times 10^{5}$ to $1.6 \times 10^{7} \mathrm{CFU} / \mathrm{mL}$ and from $3.32 \times 10^{4}$ to $2.75 \times 10^{6} \mathrm{CFU} / \mathrm{mL}$, respectively. In both, the untreated and treated wastewater, the bacteria resistant to amoxicillin (up to $80 \%$ of all bacteria), which belongs to an older generation antibiotics, were the most frequently occurring (Fig. 1).

The lowest percentage $(3 \%)$ were bacteria resistant to doxycycline which belongs to a new generation of drugs from the class of tetracyclines. Alexander et al. [4] in their study showed that WWTPs contribute to increasing of antibiotic resistance in bacterial populations, although their number was decreased. The conventional processes of wastewater treatment based on activated sludge and anaerobic digestion, create ideal conditions for horizontal gene transfer of mobile elements presented in the bacterial cells, contributing to an increase in the prevalence of antibiotic-resistant bacteria $[8,10]$. Many researchers [16, 24-26] indicate that WWTPs are not sufficiently effective in removing contaminants such as ARB or ARGs. A high concentrations of nutrients and a high concentrations of bacteria in the wastewater (particularly in the activated sludge), which is essential for effective treatment, support the spread of antibiotic resistance among bacteria. 
The most common antibiotics used in the treatment of people all over the world are penicillins, cephalosporins and carbapenems belonging to the group of beta-lactam antibiotics. The second ones are tetracyclines, which are the most popular antibiotics in animal treatment. This accounts for approximately $95 \%$ of total antibiotics used in the world. The reduction of number of bacteria resistant to beta-lactams after treatment processes ranged from 95.10 to $99.98 \%$. The highest percent of reduction in the number of bacteria resistant to both amoxicillin and cefotaxime was observed in WWTPs of the group A. These plants also most effectively reduced the number of bacteria resistant to oxytetracycline and doxycycline at the level of 99.99 and $100 \%$, respectively. The lowest percentage of reduction of the number of bacteria resistant to amoxicillin $(95.1 \%)$, oxytetracycline $(82.3 \%)$ and doxycycline $(79.4 \%)$ was observed in WWTPs belonging to group C (Table 1). Although WWTPs usually reached quite a high level of reduction in the number of antibiotic-resistant bacteria, WWTPs' effluents discharged into the environment on average from $1.05 \times 10^{2}$ to $2.77 \times 10^{5} \mathrm{CFU} / \mathrm{mL}$ (Table 1 ). It should be noted that the percentage of antibiotic-resistant bacteria in the total number of microorganisms increased after the treatment process. This was particularly noticeable in the case of WWTPs from group B, where an increase of the percentage of bacteria resistant to the older as well as newer generations of antibiotics was observed. Also Yuan et al. [19] and Korzeniewska et al. [27] reported that, despite of the high percentage of ARB reduction, discharge of wastewater causes the threat of aquatic environments.

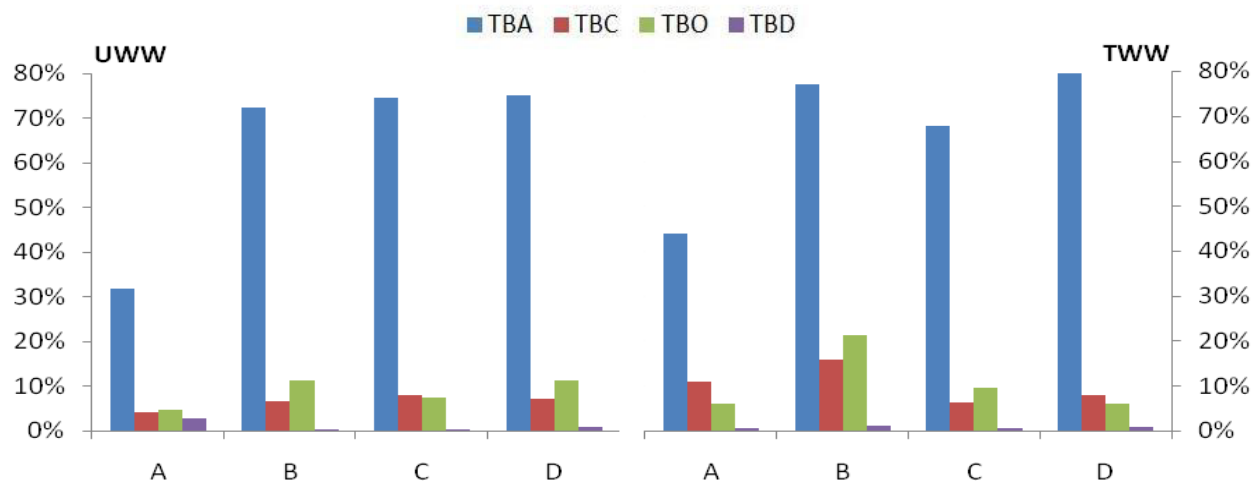

Fig. 1. The share of antibiotic resistant bacteria in total counts of microorganisms (explanation of abbreviations under Table 1).

\subsection{The total number of $E$. coli and $E$. coli resistant to beta-lactams and tertracyclines}

The excrement of animals or humans, incoming into sewage treatment plant, affected mainly on a high bacterial load of wastewater $[18 ; 28]$. Escherichia coli, which is a natural microbiota of gastrointestinal tract of humans and animals, can get into the environment directly with faeces, and indirectly with sewage effluents discharged from wastewater treatment plants. Therefore, the quantitative determinations of $E$. coli as an indicator of faecal contamination is recommended by many authors to assess the microbiological quality of the wastewater [18], as well as the contamination of aquatic ecosystems [29, 30]. The highest average number of $E$. coli were found in samples of untreated sewage from WWTPs which belongs to a group A, the lowest ones were found among WWTPs of the group B. Their number reached the amount of $6.55 \times 10^{5}$ and $9.76 \times 10^{4} \mathrm{CFU} / \mathrm{mL}$, respectively (Table 2). Regardless of the type of treatments, E. coli resistant to antibiotics 
of older generation - amoxicillin and oxytetracycline were predominant group (15-58\% and $7-12 \%$, respectively) in samples of untreated sewage. After the wastewater treatment, apart from $E$. coli resistant to amoxicillin, the dominance of $E$. coli bacteria resistant to a new generation drugs - cefotaxime and doxycycline have been also observed. Similar results were obtained by Osińska et al. [31], who indicate an increase of percentage of antibioticresistant $E$. coli in the the total number of $E$. coli in wastewater after the treatment process as well as growth of multi-drug resistance of the microorganisms.

The reduction of the number of antibiotic-resistant $E$. coli ranged from 56.7 to $99.9 \%$. The WWTPs which belongs to the group $\mathrm{C}$ were characterized by the lowest percentage of reduction. Among E. coli bacteria resistant to analyzed antibiotics in untreated wastewater, $E$. coli resistant to amoxicillin were the most frequently observed, while the most rarely were isolated $E$. coli resistant to cefotaxime $\left(4.45 \times 10^{5}\right.$ and $3.67 \times 10^{2} \mathrm{CFU} / \mathrm{mL}$, respectively). The reduction of the number of bacteria resistant to beta-lactams ranged from 0 to $99.9 \%$ (Table 2). No reduction was observed for both of bacteria resistant to amoxicillin (WWTPs belonging to groups $\mathrm{B}$ and $\mathrm{C}$ ) and cefotaxime (WWTPs belonging to groups $\mathrm{C}$ and $\mathrm{D}$ ).

Table 2. Total counts of Escherichia coli, counts of Escherichia coli resistant to beta-lactams (amoxicillin, cefotaxime) and tetracycline (oxytetracycline, doxycycline).

\begin{tabular}{|c|c|c|c|c|c|c|c|c|}
\hline & \multicolumn{2}{|c|}{ A } & \multicolumn{2}{c|}{ B $^{*}$} & \multicolumn{2}{c|}{ C } & \multicolumn{2}{|c|}{ D } \\
\cline { 2 - 9 } & $\mathbf{U W W}^{*}$ & TWW $^{* *}$ & $\mathbf{U W W}^{*}$ & $\mathbf{T W W}^{* *}$ & $\mathbf{U W W}^{*}$ & $\mathbf{T W W}^{* *}$ & $\mathbf{U W W}^{*}$ & TWW $^{* *}$ \\
\hline EC & $65.5 \pm 50$ & $\begin{array}{c}2.3 \pm 1 \\
(99.7-99.9)^{* * *}\end{array}$ & $9.8 \pm 3$ & $\begin{array}{c}18.7 \pm 1 \\
(68-99.6)\end{array}$ & $21.2 \pm 11$ & $\begin{array}{c}52.8 \pm 51 \\
(56-99.9)\end{array}$ & $23.7 \pm 1.3$ & $\begin{array}{c}13.8 \pm 1.6 \\
(99.3-99.5)\end{array}$ \\
\hline ECA & $44.5 \pm 38$ & $\begin{array}{c}2.1 \pm 2 \\
(99.96)\end{array}$ & $2.7 \pm 0.8$ & $\begin{array}{c}5.2 \pm 1.6 \\
(0-99.8)\end{array}$ & $4.8 \pm 2$ & $\begin{array}{c}25.30 \pm 24 \\
(0-99.8)\end{array}$ & $3.6 \pm 1.6$ & $\begin{array}{c}7.5 \pm 1.4 \\
(94-98.6)\end{array}$ \\
\hline ECC & $0.2 \pm 0.02$ & $\begin{array}{c}1.3 \pm 0.2 \\
(94.7-95.7)\end{array}$ & $0.1 \pm 0.03$ & $\begin{array}{c}1.4 \pm 0.7 \\
(25-99.7)\end{array}$ & $0.04 \pm 0.02$ & $\begin{array}{c}0.43 \pm 0.3 \\
(0-99.8)\end{array}$ & $0.09 \pm 0.03$ & $\begin{array}{c}4.9 \pm 2.6 \\
(0-97.5)\end{array}$ \\
\hline ECO & $2.1 \pm 1$ & $\begin{array}{c}0.3 \pm 0.07 \\
(99.6-99.9)\end{array}$ & $1.3 \pm 0.4$ & $\begin{array}{c}3.5 \pm 1 \\
(47.5-99)\end{array}$ & $1.2 \pm 0.7$ & $\begin{array}{c}8.9 \pm 2 \\
(72-99.6)\end{array}$ & $2.1 \pm 1$ & $\begin{array}{c}1.4 \pm 0.1 \\
(99.4-99.7)\end{array}$ \\
\hline ECD & $0.3 \pm 0.04$ & $\begin{array}{c}2.2 \pm 2 \\
(94-99)\end{array}$ & $0.3 \pm 0.1$ & $\begin{array}{c}0.74 \pm 0.2 \\
(5-99.51)\end{array}$ & $0.2 \pm 0.1$ & $\begin{array}{c}12.7 \pm 11 \\
(0-96.8)\end{array}$ & $0.7 \pm 0.5$ & $\begin{array}{c}1.3 \pm 0.7 \\
(87-98.5)\end{array}$ \\
\hline
\end{tabular}

${ }^{*} \mathrm{CFU} / \mathrm{mL} \times 10^{4} \quad{ }^{* *} \mathrm{CFU} / \mathrm{mL} \times 10^{2} \quad{ }^{* * *} \%$ percent of reduction in the brackets UWW - untreated wastewater, TWW - treated wastewater, CFU - colony forming unit, EC - counts of total E. coli, ECA - counts of amoxicillin resistant E. coli, ECC - counts of cefotaxime resistant $E$. coli, ECO - counts of oxytetracycline resistant E. coli, ECA - counts of doxycycline resistant $E$. coli A, B, C, D - modification of sewage treatment system.

Similar trends were also observed in the reduction of the number of bacteria resistant to tetracycline. There was also no reduction in the number of doxycycline resistant $E$. coli in WWTPs which belong to group C (Fig. 2). The lowest percentage of reduction of the number of E. coli resistant to oxytetracycline was observed in WWTPs belonging to the group B (47.5\%). The highest efficiency in the removal of bacteria resistant to both betalactams and tetracyclines, which reached up to $94-99.9 \%$, was observed for WWTPs of group A. The results of our study, which indicate an evidence of insufficient removal of ARB in WWTPs using conventional wastewater treatment systems were confirmed also by the study conducted by many authors [24,32].

Despite the significant reduction of the number of antibiotic-resistant $E$. coli, we noted that after the sewage treatment process the percentages of $E$. coli bacteria resistant to all tested antibiotics increased in wastewater treated in WWTPs belonging to groups B, C and D. However, in wastewater treated in WWTPs of group A, the percentage of bacteria resistant to antibiotics from old generation was decreased. The percentage of bacteria resistant to cefotaxime and doxycycline, which are antibiotics from new generation groups, in the total number of $E$. coli has been increased. Some researchers [28, 33] suggest that WWTPs are effective in removal of bacteria, including indicator bacteria like E. coli. 
However, there are also studies which suggest that the number of bacteria did not decrease after the wastewater treatment processes, regardless of the type of treatment [34].

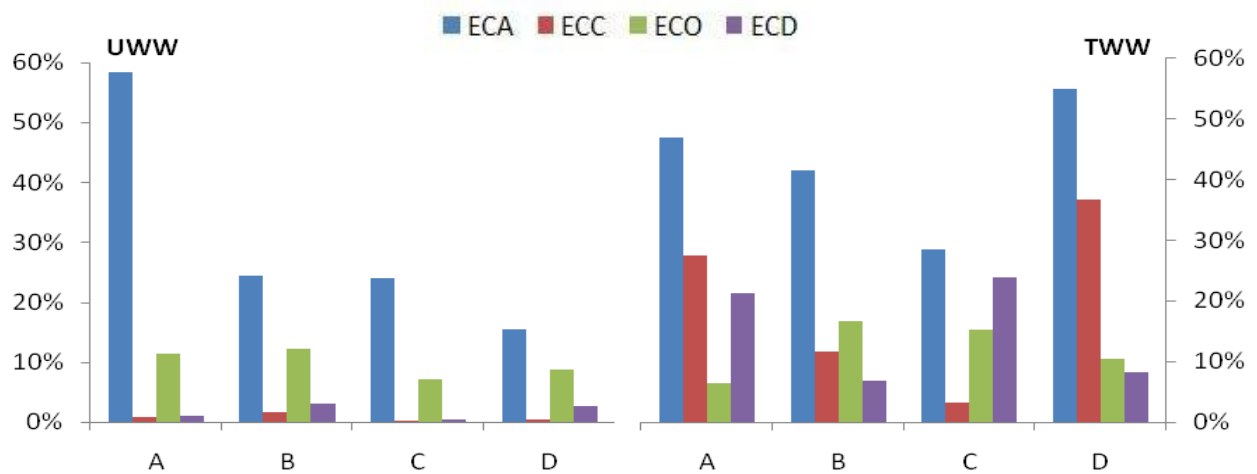

Fig. 2. The share of antibiotic resistant Escherichia coli in total counts of E. coli (explanation of abbreviations under Table 2).

\section{Conclusions}

The presented results indicate that wastewater treatment plants are an important source of antibiotic-resistant bacteria. They also indicate different level of removal of antibioticresistant bacteria, depending on the technology used for wastewater treatment. The highest percent of reduction in number of ARB (at least 99.9\%) and E. coli (above 99.3\%) was obtained for WWTPs with $\mathrm{A}_{2} \mathrm{O}$ system. Although most of WWTPs showed a high efficiency of reduction of the number of antibiotic-resistant bacteria during the treatment process, they continue discharge with treated wastewater the massive amounts of microorganisms into the natural environment. Futhermore, the studies have shown that during the wastewater treatment process, the percentage of antibiotic-resistant bacteria in the total number of bacteria underwent increase. The presented results indicate that some technological solutions used by WWTPs insufficiently reduced the number of antibioticresistant E. coli, which is a serious threat to public health. This indicates the need of improving of new modification of wastewater treatment processes and continuous monitoring of treated sewage discharged into the environment.

\section{References}

1. A. F. Leonard, L. Zhang, A.J. Balfour, R. Garside, W. H. Gaze, Environ. Int. 82 (2015)

2. J. O’Neill, http://amrreview.org/sites/default/files/160525 Final\%20paper_with \% 20cover.pdf (2014)

3. ECDC, European Centre for Disease Prevention and Control. Antimicrobial consumption interactive database (ESAC-Net). http://ecdc.europa.eu/en/ healthtopics/antimicrobial-resistance-and-consumption (2015)

4. J. Alexander, A. Bollmann ,W. Seitz, T. Schwartz, Sci. Total Environ. 512-513 (2015)

5. M. A. Shannon, P. W. Bohn, M. Elimelech, J. G. Georgiadis, Mariñas, B. J., Mayes, A. M., Nature 452 (2008)

6. R. M. Carr, U. J. Blumenthal, D.D. Water Sci. Technol. 50 (2004) 
7. J. L. Martinez, T.M. Coque, F. Baquero, Nat. Rev. Microbiol. 13 (2015)

8. L. S. Frost, R. Leplae, A. O. Summers, A. Toussaint, Nat. Rev. Microbiol. 3 (2005)

9. J. Davies, Are antibiotics naturally antibiotics? J. Ind. Microbiol. Biotechnol. 33, 7 (2006)

10. E. Marti, B. Huerta, S. Rodríguez-Mozaz, D. Barceló, J. Jofre, J. L. Balcázar, Water Res. 61 (2014)

11. J. L. Martinez, Science 321 (2008)

12. B. Berglund, J. Fick, P. E. Lindgren, Environ. Toxicol. Chem. 34 (2015).

13. L. Rizzo, C. Manaia, C. Merlin, T. Schwartz, C. Dagot, M. C. Ploy, I. Michael, D. Fatta- Kassinos, Sci. Total Environ.447 (2013)

14. T. Yang, Z. Zeng, L. Rao , X. Chen, D. He, L. Lv, J. Wang, L. Zeng, M. Feng, J. H. Liu, Vet. Microbiol. 170 (2014)

15. E. Kotlarska, A. Łuczkiewicz, M. Pisowacka, A. Burzyński, Environ. Sci. Pollut. Res. 22 (2015)

16. A. Pruden, Environ. Sci. Technol. 48 (2014)

17. L. K. Dick, E. A. Stelzer, E. E. Bertke, D. L. Fong, D. M. Stoeckel, Appl. Environ. Microbiol. 76 (2010)

18. J. D. Dubreuil, Curr. Issues Mol. Biol. 14 (2012)

19. Q. B. Yuan, M. T. Guo, J. Yang, Environ. Sci.: Processes Impacts, 16 (2014)

20. F. F. Reinthaler, J. Posch , G. Feierl, G. Wust, D. Haas , G. Ruckenbauer, F. Mascher, E. Marth, Water Res. 37 (2003)

21. S. Borjesson, S. Melin, A. Matussek and P. E. Lindgren, Water Res., 43, 4 (2009)

22. APHA, American Public Health Association, Standard Methods for the Examination of Water and Wastewater, 20th ed. Washington D.C. (1998)

23. EUCAST, European Committee on antimicrobial susceptibility testing. Breakpoints tables for interpretation of MICs and zones diameters. Version 4.0, http://www.eucast.org (2014)

24. D. Rafraf, I. Lekunberri, A.Sànchez-Melsió, M. Aouni, C. M. Borrego, J. L. Balcázar, Environ. Pollut. 219 (2016)

25. E. Korzeniewska, M. Harnisz, J. Environ. Manage., 128 (2013)

26. M. Harnisz, E. Korzeniewska, I. Gołaś, Chemosphere 128 (2015)

27. E. Korzeniewska, A. Korzeniewska, M. Harnisz, Ecotox. Environ. Safe., 91 (2013)

28. R. Hendricks, E. J. Pool, J. Environ. Sci. Health A Tox. Hazard Subst. Environ. Eng. 47 (2012)

29. S. Li, S. Wengang, Z. Yufa, T. Yujing, G Yanxia, M. Zengmin, Environ. Sci. Pollut. Res. 22 (2015)

30. Y. Titilawo, L. Obi, A. Okoh, Sci. Total Environ. 523 (2015)

31. A. Osińska, E. Korzeniewska, M. Harnisz, S. Niestępski, Sci. Total Environ. 15 (2017)

32. S. Rodriguez-Mozaz, S. Chamorro, E. Marti, B. Huerta, M. Gros, A. Sànchez-Melsió, C. M. Borrego, D. Barceló, J.L. Balcázar, Water Res. 69 (2015)

33. M. Oliveira, I. Serrano, S. Van Harten, L.J. Bessa, F. Bernardo, P.M. da Costa, Environ. Sci.Pollut. Res. 23 (2016)

34. V. K. Sharma, N. Johnson, L. Cizmas, T. J. McDonald, H. Kim Chemosphere 150, (2016) 